\title{
Changes in mammary uptake and metabolic fate of glucose with once-daily milking and feed restriction in dairy cows
}

\author{
Jocelyne GuINARD-FlaMENT*, Eloise DELAMAIRE, \\ Sophie LEMOSQUET, Marion BouTINAUD, Yolande DAVID \\ UMR INRA/Agrocampus Rennes Production du Lait, 65 rue de St-Brieuc, CS 84215, \\ 35042 Rennes Cedex, France
}

\begin{abstract}
The aim of this review is to better understand the regulation of milk yield in response to once-daily milking and feed restriction. Glucose is the principal precursor for the synthesis of lactose (a major osmotic agent in milk), and participates in determining the milk volume produced. When applying these two breeding factors, reductions in milk yield are associated with a reduction in milk lactose yield and in the arterial flow of glucose, due to a decrease in the mammary blood flow. The ability of the udder to extract glucose is altered with once-daily milking but not necessarily with feed restriction. Lactose synthesis is down-regulated in response to once-daily milking and feed restriction but the percentage of the extracted glucose which is converted into lactose is differently affected in response to treatments. No marked change is observed with once daily milking whereas this would be increased with feed restriction and in contrast, depressed with fasting.
\end{abstract}

milk yield / glucose / mammary gland / uptake / metabolic fate / ruminants

\section{INTRODUCTION}

Once-daily milking and feed restriction are known to affect the milk performance of dairy cows. A change to once-daily milking induces a major reduction in the milk yield of cows averaging $20-30 \%$ but ranging from 7 to $50 \%$ according to trials $[1,2]$. Similarly, a marked reduction in feed intake can generate similar variations in milk yield with lower responses in early lactation than in mid lactation [3]. Only few studies have analysed the effects of both once-daily milking and feed restriction [4-7]. No significant interactions were observed during most of these studies. An-

\footnotetext{
* Corresponding author:

Jocelyne.Flament@agrocampus-rennes.fr
}

imals changing to once-daily milking with a reduced feed intake endured a drop in their milk yield because of the effects of both. Nevertheless, Auldist and Prosser [4] reported a more marked reduction in milk yield in cows with access to unlimited hay than in those with feed restriction, when once-daily milking was applied for two days ( -4.2 vs. $-2.3{\mathrm{~kg} . \mathrm{day}^{-1}}^{-1}$.

The drop in milk yield observed in response to once-daily milking and feed restriction is accompanied by a reduction in mammary gland lactose production $[1,2$, $8,9]$. Lactose is a highly osmotic component, which allows the drainage of water from blood to the alveolar compartment. As such, it is the principal milk component regulating the volume of milk 
produced by the animals, and its concentration in milk remains relatively stable, around 4.4-5.2\% [10].

As glucose is the principal precursor of lactose, these milk lactose losses can be explained by a change of the mammary utilisation of glucose [11]. Regulation of the milk yield of animals is therefore mainly based on the mechanisms governing the quantity of glucose extracted by the udder and converted into lactose. In the mammary gland, these mechanisms can be broken down into three main levels of regulation, which are the arterial flow of glucose in the mammary gland, the glucose extraction by the udder and the metabolic and secretion activities of the mammary epithelial cells.

Once-daily milking and feed restriction could regulate milk yield differently because signals giving rise to milk losses are different. Indeed, once-daily milking can provoke a reduction in milk yield due to mechanisms related to lower discharge of hormones specifically released at milking and the effects of milk accumulation in mammary alveoli. On the other hand, feed restriction causes a reduction in milk yield through mechanisms related to the availability of nutrients in the body.

The aim of this bibliographical review is to highlight the regulatory mechanisms underlying marked milk losses, by providing an updated summary of the results obtained concerning glucose utilisation by the udder, under the effect of once-daily milking and marked feed restriction. The mammary use of glucose will be recalled before describing how these two factors can cause major reductions in milk yield.

\section{THE MAMMARY UTILISATION OF GLUCOSE}

The udder cannot synthesize its own glucose (lack of glucose-6- phosphatase, [12]), which must therefore be extracted from circulating blood. The udder extracts most of the glucose available in the whole body (between 60 and $85 \%$ ). The mammary uptake of glucose is mainly determined by the quantity of blood irrigating this organ, the arterial glucose concentration and the udder's ability to extract glucose from blood plasma. Arterial glucose concentrations reflect the balance between glucose input and output in the body. The quantity of blood irrigating the udder results from complex regulatory mechanisms, depending both on the partitioning of cardiac flow between different tissues in the body and local regulation which allows a given organ to adjust its arterial nutrient flow to its level of metabolic activity. In lactating cows, $15-16 \%$ of the cardiac output is delivered to the udder and whole mammary blood flow averaged 7 L.min ${ }^{-1}$ in cows producing $16 \mathrm{~kg}$ of milk daily [13]. The udder's efficiency to extract glucose from blood plasma is relatively poor; the glucose extraction rate (arteriovenous difference in glucose concentrations divided by the arterial glucose concentration) is on average $26 \%[14,15]$ and can fall to $15 \%$ in dairy cows [16]. According to Rulquin in 1997 [15], the arteriovenous differences in glucose concentration in the udder appear to be relatively independent of the variations in the arterial glucose concentration. Thus the extraction efficiency of glucose by the udder could depend mainly on the capacity for transmembrane transport and/or intracellular metabolism of glucose. However, in mammary epithelial cells of ruminants, Zhao et al. [17] admitted that, under normal physiological conditions, the GLUT1 transporter protein which predominates in the bovine mammary gland [17-19], is probably never saturated. Thus regulation of glucose extraction by bovine mammary epithelial cells may occur at another level than transmembrane transport [20]. 


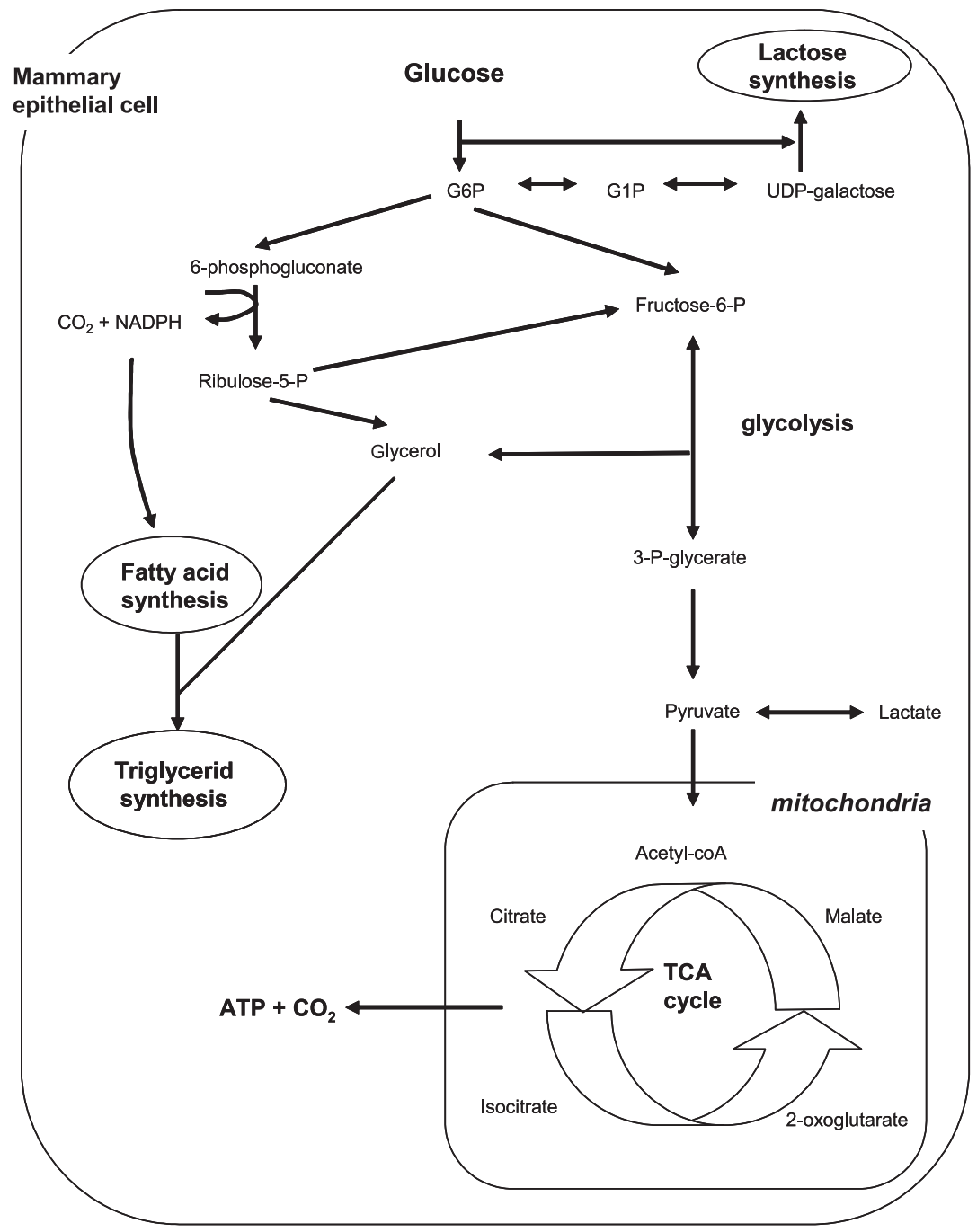

Figure 1. Description of the intracellular partitioning of glucose between different metabolic pathways in mammary epithelial cells.

Glucose extracted by the mammary gland has several possible metabolic fates in mammary epithelial cells (Fig. 1). Depending on trials, its partitioning between the metabolic pathways varies and the reasons of such variations remain unclear. Approximately 55 to $70 \%$ of the glucose extracted by the mammary gland is used to synthesize lactose [21-23]. Lactose is synthesized from one molecule of glucose and one of galactose. According to Davis and Bauman [21], 50 to $60 \%$ of the glucose in the glucose-6-phosphate pool is converted into galactose. Seventy percent of the galactose would derive from extracted glucose, as well as from glycerol and other metabolic pathways [10]. Thus glucose is not the sole carbon source for 
lactose synthesis but remains the main one; $80-85 \%$ of lactose carbon atoms arise from glucose $[11,24]$. The remaining 30-40\% of extracted glucose can participate in the supply of ATP (glycolysis and TCA cycle). It can also participate in the milk fat formation, by supplying the glycerol (triose phosphate pathway) and the NADPH essential to elongating milk fatty acids (pentose phosphate and isocitrate deshydrogenase pathways). Very marginally, glucose can supply carbon atoms for the synthesis of non-essential amino acids.

\section{EFFECT OF ONCE-DAILY MILKING ON THE THREE LEVELS OF MAMMARY REGULATION}

\subsection{The arterial flow of glucose in the mammary gland}

Once-daily milking causes variations in the arterial concentration of glucose. During studies conducted short-term or throughout lactation in the dairy cow, a significant increase of 7-8\% in plasma glucose concentrations was demonstrated [4, 25]. Despite these findings, the amount of glucose irrigating the mammary gland could diminish because of a reduction in the mammary blood flow which is greater than the increase in the arterial concentration. Indeed, the mean daily blood flow was seen to diminish by $10 \%$ in dairy cows producing $23 \mathrm{~kg}$ of milk per day in response to a change to once-daily milking [26]. In dairy cows producing $38 \mathrm{~kg}$ of milk per day, the blood flow decreased by $17 \%$ linearly when the milking interval increased from 8 to $24 \mathrm{~h}$ [27]. During this latter study, the reduction in the mammary blood flow started from the first day of treatment, but only became significant after seven days (unpublished data). The almost immediate adaptation of the mammary blood flow was amplified during treatment, suggesting its regulation in two ways: a physical effect linked to milk accumulation in the mammary gland and a gradual metabolic adjustment linked to the metabolic activity of the organ. During a study of the blood microcirculation in the goat mammary gland, Farr et al. [28] deduced that the number of capillaries recruited diminished when milk accumulated in the udder for 26-28 h.

\subsection{Glucose extraction}

Fleet and Peaker [29] studied the mammary extraction of various nutrients in goats towards the end of lactation. After $48 \mathrm{~h}$ of milk accumulation in the udder, reduction in the mammary consumption of glucose $(-75 \%)$ was demonstrated. The reduction in glucose consumption tended to result from impairment of both mammary blood flow and the mammary gland's extraction ability. In dairy cows, Delamaire and Guinard-Flament [25] also observed a reduction in the glucose extraction rate, which fell from 27 to $23 \%$ in response to increasing the milking interval from $8 \mathrm{~h}$ to $24 \mathrm{~h}$.

\subsection{Metabolic and secretion activities}

Once-daily milking affects the metabolic activity of mammary epithelial cells without major alteration of the glucose repartition between the metabolic pathways. Indeed, Delamaire and GuinardFlament [27] reported an unchanged mammary efficiency in converting the extracted glucose into lactose while increasing milking intervals from 8 to $24 \mathrm{~h}$.

The activity of mammary epithelial cells could be depressed through two mechanisms which involve both the activity of cells and their number. A reduction in the amount of lactose produced may result 
from its impaired synthesis. Net enzyme activity is determined by the quantity of enzymes or co-factors ( $\alpha$-lactalbumin). After three weeks of once-daily milking, the enzymatic activity of galactosyltransferase was reduced by $33 \%[30,31]$. Two studies showed that a reduction in milking frequency had no effect on the level of $\alpha$ lactalbumin gene expression $[32,33]$. Reduction in milking frequency also reduced the activity of the other major enzymes involved in mammary metabolism (acetyl co-enzyme A carboxylase, fatty acid synthetase) [31]. In parallel to its effects on metabolic activity, four weeks of oncedaily milking gave rise to the apoptosis (i.e. cell death) of some mammary cells [34]. In the goat, Boutinaud et al. [33] observed smaller alveolar diameters and lower numbers of mammary epithelial cells when once-daily milking was compared with milking three times a day.

Once-daily milking may also reduce the secretory activity of mammary epithelial cells. In cows not milked for $48 \mathrm{~h}$, Holst et al. [35] observed an accumulation of Golgi vesicles and lipid droplets in mammary epithelial cells. If colchicine (which is known to destructure the cytoskeleton) was injected via the teat canal, similar effects were observed [36]. According to Stelwagen [37], the migration of secretory vesicles could be disturbed by an accumulation of milk in the mammary alveoli because of modifications to the cytoskeleton orchestrated by the opening of tight junctions.

\section{EFFECT OF FEED RESTRICTION ON THE THREE LEVELS OF MAMMARY REGULATION}

\subsection{Arterial flow of glucose in the mammary gland}

Blood glucose concentrations are influenced by both the quality and level of feed intake $[38,39]$. Energy restrictions cause a linear reduction in the entry of glucose into the whole body and result in a lowering of arterial glucose levels [40]. In the goat, fasting for between 6 and $48 \mathrm{~h}$ caused a very marked reduction in milk yield, reaching around 56-72\% [41, 42]. This harmful effect on milk yield was principally due to a lower nutrient flow into the udder, related to a 40 to $70 \%$ reduction in the mammary blood flow [41-44]. In the cow, the mammary blood flow was shown to be halved after fasting for $24 \mathrm{~h}$, and only returned to normal 10 to $12 \mathrm{~h}$ after feeding restarted [13]. Similarly, Lough et al. [45] observed a 5.1 to $4.3 \mathrm{~L} \cdot \mathrm{min}^{-1}$ reduction in the mammary blood flow during a $70 \%$ restriction of feed. A lowering of the heart rate was observed in heifers not receiving concentrate [46]. In the cow, cardiac output and that proportion of the cardiac output allocated to the mammary gland fell by 23 and $53 \%$, respectively, in response to fasting for $24 \mathrm{~h} \mathrm{[13].} \mathrm{Similarly,} \mathrm{they} \mathrm{fell} \mathrm{by} 36$ and $52 \%$, respectively, in goats fasted for 48 h [42]. According to Farr et al. [28], a smaller quantity of blood passed through the same number of capillaries in the udder of the goat in response to fasting for $18-20 \mathrm{~h}$.

\subsection{Glucose extraction}

In response to feed restrictions or varying energy intakes, the mammary gland reacts differently depending on the degree of the deficit and the type of energy provided. In the cow, arteriovenous differences in glucose concentrations fell in the udder during a reduction in dietary energy levels [47]. In the goat, the quantities of glucose extracted by the udder diminished during $48 \mathrm{~h}$ fasting [48]. In the female rat, fasting overnight provoked a reduction of up to $90 \%$ in glucose uptake by the mammary gland [49]. Prosser [50] observed that the fasting of mice for $16 \mathrm{~h}$ led to a 
reduction in the number of active glucose transporters in the plasma membrane. $\mathrm{He}$ suggested the existence of a GLUT1 transmembrane transporter translocation from the plasma membrane to an intracellular site.

\subsection{Metabolic and secreting activities}

During dietary restriction in ruminants, lactose synthesis diminishes considerably, while the activity of galactosyltansferase is not affected [51]. According to Chaiyabutr et al. [48], the reduction in the quantity of glucose extracted by the udder may result from impaired glucose phosphorylation by hexokinase. This enzyme may be inhibited by high concentrations of glucose-6-phosphate in the cytosol. Indeed, intracellular concentrations of glucose-6-phosphate have been shown to increase two or three-fold during fasting for $48 \mathrm{~h}$ in the goat. Furthermore, the partitioning of glucose-6-phosphate between different metabolic pathways may be disturbed [52]: during fasting, the metabolism of glucose-6-phosphate declines in response to a reduction in the glucose-6phosphate flux towards the pentose phosphate pathway and in lactose synthesis. In parallel, a higher proportion of glucose-6phosphate is metabolised via the glycolysis pathway.

Feed deprivation is an extreme case which applies to short periods and may result in specific regulatory mechanisms. An increase in the forage to concentrate ratio from 50 to $87.5 \%$ [53] (or a less drastic restriction) modified the intra-mammary metabolism of glucose, but in a slightly different way. Indeed, this treatment caused an increase in the percentage of glucose used to synthesize lactose from 55 to $62 \%$, and in the quantity of NADPH produced in the pentose phosphate pathway from glucose from 15 to $36 \%$. In addition, in cows under feed restrictions for 8 weeks, a tendency towards a reduction in galac- tosyltransferase activity in the udder was observed [54]. Similarly, the number of mammary epithelial cells was also modified because of a significantly lower proliferation of mammary epithelial cells in cows under feed restrictions [54].

\section{CONCLUSION}

This bibliographical report describes the respective effects of once-daily milking and feed restriction on the glucose utilisation by the mammary gland. Very few studies have quantified the effects of these factors on the mammary arterial flow, extraction and intracellular fate of glucose in ruminants. Data are sometimes lacking and results are not always consistent. This can be partly explained by the diversity of treatments tested, especially with regard to the intensity of feed restriction. In addition, more findings available are concerning fasting which may involve different regulations compared to feed restriction.

Nevertheless, in view of the results obtained, it appears that a loss in milk yield is accompanied by modifications at all levels of regulation of the glucose utilisation by the mammary gland (Tab. I). Reductions in milk volume and lactose yield are both associated with a reduction in the arterial flow of glucose in the mammary gland, because of a reduced mammary blood flow associated with an increased or inversely depressed arterial concentration of glucose in response to once-daily milking and feed restriction, respectively. Glucose extraction appears to be impaired with once-daily milking, but not necessarily with feed restriction. As a result, high milk losses are associated with lower amounts of glucose taken up by the udder. However, once-daily milking and feed restriction seem to act differently probably by generating different chains of mechanisms that would finally act on mammary blood flow and glucose extraction. 
Table I. Partial list of changes in mammary glucose metabolism associated with once-daily milking and feed restriction in ruminants.

\begin{tabular}{|c|c|c|c|}
\hline$\overline{\text { Glucose }}$ & Once-daily milking & \multicolumn{2}{|c|}{ Feed restriction } \\
\hline Mammary arterial flow & $\downarrow$ & \multicolumn{2}{|c|}{$\downarrow$} \\
\hline Plasma concentrations & $\uparrow$ & \multicolumn{2}{|c|}{$\downarrow$} \\
\hline Mammary blood flow & $\downarrow$ & \multicolumn{2}{|c|}{$\downarrow$} \\
\hline Extraction rates & $\downarrow$ & \multicolumn{2}{|c|}{ ? } \\
\hline Mammary uptake & $\downarrow$ & \multicolumn{2}{|c|}{$\downarrow$} \\
\hline \multicolumn{4}{|l|}{ Intracellular fate (\%) } \\
\hline Lactose production & $\rightarrow$ & $\downarrow$ (fasting) & $\uparrow$ (restriction) \\
\hline Glycerol production & ? & & \multirow{3}{*}{$\uparrow$ (restriction) } \\
\hline Pentose phosphate pathway & ? & $\downarrow$ (fasting) & \\
\hline ATP production & ? & $\uparrow$ (fasting) & \\
\hline
\end{tabular}

$\uparrow, \downarrow, \rightarrow$, variable increased, decreased or unchanged in response to once-daily milking or feed restriction, respectively; ? changes unkown.

In the mammary epithelial cells, the metabolism of glucose is depressed in response to once-daily milking and feed restriction. However, these factors would also act differently on cell activity. With once-daily milking, the efficiency of the mammary gland to convert glucose would be preserved as suggested by the unchanged glucose uptake/milk lactose output ratio. Thus the partitioning of glucose between its mammary metabolic pathways might be unchanged or slightly modified, $70 \%$ of it being always converted into lactose. In contrast, when the level of feeding is reduced, the intracellular fate of glucose would be greatly modified according to the extent of the feed restriction. Indeed, in case of starvation, lactose synthesis and pentose phosphate pathway would be depressed to the profit of glycolysis pathway. In contrast, with feed restriction, the use of glucose towards lactose synthesis and pentose phosphate pathway would be enhanced. Hence the volume of milk produced by animals is related to a great extent to the quantity of glucose extracted from blood compartment but its partitioning between the different metabolic pathways in mammary epithelial cells could be of ma- jor importance in determining milk yield and composition.

Furthermore, an interaction between once-daily milking and feed restriction on the different levels of regulation of the mammary glucose utilisation has never, to our knowledge, been studied. This area merits attention in order to understand the additive effects of once-daily milking and feed restriction on milk yield, and mechanisms responsible for milk yield losses.

\section{ACKNOWLEDGEMENTS}

The authors are grateful to A. Pinhouët for assistance and thank V. Hawken for the English translation.

\section{REFERENCES}

[1] Davis SR, Farr VC, Stelwagen K. Regulation of yield loss and milk composition during once-daily milking: a review. Livest Prod Sci 1999, 59: 77-94.

[2] Rémond B, Pomiès D. Once-daily milking of dairy cows: a review of recent French experiments. Anim Res 2005, 54: 427-442. 
[3] Coulon JB, Rémond B. Variations in milk output and milk protein content in response to the level of energy supply to the dairy cow: a review. Livest Prod Sci 1991, 29: 31-47.

[4] Auldist MJ, Prosser CG. Differential effects of short-term once-daily milking on milk yield, milk composition and concentrations of selected blood metabolites in cows with low or high pasture intake. Proc NZ Soc Anim Prod 1998, 58: 41-43.

[5] Lacy-Hulbert SJ, Woolford MW, Nicholas GD, Prosser CG, Stelwagen K. Effect of milking frequency and pasture intake on milk yield and composition of late lactation cows. J Dairy Sci 1999, 82: 1232-1239.

[6] Rémond B, Aubailly S, Chilliard Y, Dupont $\mathrm{D}$, Pomiès D, Petit M. Combined effects of once-daily milking and feeding level in the first three weeks of lactation on milk production and enzyme activities, and nutritional status, in Holstein cows. Anim Res 2002, 51: 101-117.

[7] Rémond B, Pomiès D, Pradel P. Effet de la monotraite des vaches laitières sur leur production, selon le niveau de distribution d'aliments concentrés. $12^{\mathrm{e}}$ Rencontre Recherche Ruminants, 2005, p 229-232.

[8] Johnson CL. The effect of feeding in early lactation on feed intake, yields of milk, fat and protein and on live-weight change over one lactation cycle in dairy cows. J Agric Sci Camb 1984, 103: 629-637.

[9] Friggens NC, Emmans GC, Kyriazakis I, Oldham JD, Lewis M. Feed intake relative to stage of lactation for dairy cows consuming total mixed diets with a high or low ratio of concentrate to forage. J Dairy Sci 1998, 81: 2228-2239.

[10] Kaufmann W, Hagemeister H. Composition of milk. In: HO Gravert (Ed), Dairy-cattle production. Elsevier Science Publishers BV, Amsterdam, 1987, p 107-171.

[11] Faulkner A, Peaker M. Regulation of mammary glucose metabolism in lactation. In: MC Neville, Daniel CW (Eds), The Mammary gland: development, regulation and function, Plenum Press, New York, 1987, p 535-562.

[12] Scott RA, Bauman DE, Clark JH. Cellular gluconeogenesis by lactating bovine mammary tissue. J Dairy Sci 1976, 59: 50-56.
[13] Davis SR, Collier RJ. Mammary blood flow and regulation of substrate supply for milk synthesis. J Dairy Sci 1985, 68: 1041-1058.

[14] Annison EF, Bickerstaffe R, Linzell JL. Glucose and fatty acid metabolism in cows producing milk of low fat content. J Agric Sci Camb 1974, 82: 87-95.

[15] Rulquin H. Régulation de la synthèse et de la sécrétion des constituants du lait chez les ruminants. $4^{\mathrm{e}}$ Rencontre Recherche Ruminants, 1997, p 327-338.

[16] Rulquin H. Effects on digestion and metabolism in the dairy cow of infusions of volatile fatty acids into the rumen and caseinate into the duodenum. II. General and mammary metabolism. Reprod Nutr Dev 1983, 23: 1029-1042.

[17] Zhao FQ, Moseley WM, Tucker HA, Kennelly JJ. Regulation of glucose transporter gene expression in mammary gland, muscle, and fat of lactating cows by administration of bovine growth hormone and bovine growth hormone-releasing factor. J Anim Sci 1996, 74: 183-189.

[18] Zhao FQ, Glimm DR, Kennelly JJ. Distribution of mammalian facilitative glucose transporter messenger RNA in bovine tissues. Int J Biochem 1993, 25: 1897-1903.

[19] Komatsu T, Itoh F, Kushibiki S, Hodate K. Changes in gene expression of glucose transporters in lactating and nonlactating cows. J Anim Sci 2005, 83: 557-564.

[20] Xiao C, Cant JP. Glucose transporter in bovine mammary epithelial cells is an asymmetric carrier that exhibits cooperativity and trans-stimulation. Am J Physiol, Cell Physiol 2003, 285: C1226-C1234.

[21] Davis CL, Bauman DE. General metabolism associated with synthesis of milk. In: BL Larson, Smith VR (Eds), Lactation: a comprehensive treatise, Academic Press, New York, 1974, p 3-29.

[22] Baldwin RL, Smith NE. Milk production in dynamic biochemistry of animal production. PM Riis (Ed), Elsevier Science Publisher BV, Amsterdam, 1983, p 359-386.

[23] Knight CH, Dewhurst RJ. Once daily milking of dairy cows: relationship between yield loss and cisternal milk storage. J Dairy Res 1994, 61: 441-449.

[24] Bickerstaffe R, Annison EF, Linzell JL. Metabolism of glucose, acetate, lipids and 
amino acids in lactating dairy cows. J Agric Sci Camb 1974, 82: 71-85.

[25] Delamaire E, Guinard-Flament J. Longer milking intervals alter mammary epithelial permeability and the udder's ability to extract nutrients. J Dairy Sci 2006, 86: 2007 2016.

[26] Guinard-Flament J, Rulquin H. Effect of once vs. twice daily milking on mammary blood flow (MBF) in dairy cows. Livest Prod Sci 2000, 70: 180 .

[27] Delamaire E, Guinard-Flament J. Increasing milking intervals decreases the mammary blood flow and mammary uptake of nutrients in dairy cows. J Dairy Sci 2006, 89: 3439_ 3446.

[28] Farr VC, Prosser CG, Davis SR. Effects of mammary engorgement and feed withdrawal on microvascular function in lactating goat mammary glands. Am J Physiol Heart Circ Physiol 2000, 279: H1813-H1818.

[29] Fleet IR, Peaker M. Mammary function and its control at the cessation of lactation in the goat. J Physiol 1978, 279: 491-507.

[30] Wilde CJ, Knight CH. Milk yield and mammary function in goats during and after once-daily milking. J Dairy Res 1990, 57: 441-447.

[31] Farr VC, Stelwagen K, Kerr MA, Davis SR, Eichler SJ. Effect of once daily milking $(\mathrm{ODM})$ on enzyme activities in the bovine mammary gland. Proc NZ Soc Anim Prod 1995, 55: 12-13.

[32] Bryson JM, Wilde CJ, Addey CV. Effect of unilateral changes in milking frequency on mammary mRNA concentrations in the lactating goat. Biochem Soc Trans 1993, 21: $294 \mathrm{~S}$.

[33] Boutinaud M, Rousseau C, Keisler DH, Jammes H. Growth hormone and milking frequency act differently on goat mammary gland in late lactation. J Dairy Sci 2003, 86: 509-520.

[34] Li P, Rudland PS, Fernig DG, Finch LM, Wilde CJ. Modulation of mammary development and programmed cell death by the frequency of milk removal in lactating goats. J Physiol 1999, 519: 885-900.

[35] Holst BD, Hurley WL, Nelson DR Involution of the bovine mammary gland: histological and ultrastructural changes. J Dairy Sci 1987, 70: 935-944.
[36] Hurley WL. Mammary gland function during involution. J Dairy Sci 1989, 72: 1637 1646.

[37] Stelwagen K. Effect of milking frequency on mammary functioning and shape of the lactation curve. J Dairy Sci 2001, 84: E204-E211.

[38] McClure TJ. Effects of food intake and composition on the concentration of glucose in the blood of lactation cattle. Aust J Agric Res 1977, 28: 333-339.

[39] McClure TJ. Effect of feed quality and stage of lactation on the concentration of glucose in the blood of lactating cattle. Aust J Agric Res 1977, 28: 341-344.

[40] Wieghart M, Slepetis R, Elliot JM, Smith DF. Glucose absorption and hepatic gluconeogenesis in dairy cows fed diets varying in forage content. J Nutr 1986, 116: 839-850.

[41] Linzell JL. The effect of infusions of glucose, acetate and amino acids on hourly milk yield in fed, fasted and insulin-treated goats. J Physiol 1967, 190: 347-357.

[42] Chaiyabutr N, Faulkner A, Peaker M. Effects of starvation on the cardiovascular system, water balance and milk secretion in lactating goats. Res Vet Sci 1980, 28: 291-295.

[43] Kronfeld DS, Raggi F, Ramberg CF. Mammary blood flow and ketone body metabolism in normal, fasted, and ketotic cows. Am J Physiol 1968, 215: 218-227.

[44] Jones RG, Williamson DH. Alterations in mammary-gland blood flow and glucose metabolism in the lactating rat induced by short-term starvation and refeeding. Biosci Rep 1984, 4: 421-426.

[45] Lough DS, Beede DL, Wilcox CJ. Effects of feed intake and thermal stress on mammary blood flow and other physiological measurements in lactating dairy cows. J Dairy Sci 1990, 73: 325-332.

[46] Brosh A, Aharoni Y, Degen AA, Wright D, Young B. Estimation of energy expenditure from heart rate measurements in cattle maintained under different conditions. J Anim Sci 1998, 76: 3054-3064.

[47] Hartmann PE, Lascelles AK. The effect of starvation on the uptake of the precursors of milk fat by the bovine mammary gland. Aust J Biol Sci 1965, 18: 1025-1034. 
[48] Chaiyabutr N, Faulkner A, Peaker M Changes in the concentrations of the minor constituents of goat's milk during starvation and on refeeding of the lactating animal and their relationship to mammary gland metabolism. Br J Nutr 1981, 45: 149-157.

[49] Threadgold LC, Kuhn NJ. Monosaccharide transport in the mammary gland of the intact lactating rat. Biochem J 1984, 218: 213-219.

[50] Prosser CG. Mechanism of the decrease in hexose transport by mouse mammary epithelial cells caused by fasting. Biochem J 1988, 249: 149-154.

[51] Wilde CJ, Kuhn NJ. Lactose synthesis in the rat, and the effects of litter size and malnutrition. Biochem J 1979, 182: 287-294.
[52] Chaiyabutr N, Faulkner A, Peaker M. The utilization of glucose for the synthesis of milk components in the fed and starved lactating goat in vivo. Biochem J 1980, 186: 301-308.

[53] Chaiyabutr N, Komolvanich S, Preuksgorn $\mathrm{S}$, Chanpongsang S. Comparative studies on the utilization of glucose in the mammary gland of crossbred holstein cattle feeding on different types of roughage during different stages of lactation. Asian-Australas J Anim Sci 2000, 13: 334-347.

[54] Norgaard J, Sorensen A, Sorensen MT, Andersen JB, Sejrsen K. Mammary cell turnover and enzyme activity in dairy cows: effects of milking frequency and diet energy density. J Dairy Sci 2005, 88: 975-982. 